\title{
KEEFEKTIFAN PEMBELAJARAN KETERAMPILAN BERTANYA DENGAN METODE QUESTION STUDENT HAVE SISWA KELAS VII SMP NEGERI 1 SINJAI
}

\author{
Ilham Bachtiar* \& Busyairi Ahmad** \\ Institut Ilmu Sosial dan Ilmu Politik (IISIP YAPIS) Biak \\ *imazzahra1@gmail.com \\ **busyairiahmad90@gmail.com
}

\begin{abstract}
The objective of this research was to prove the learning effectiveness of seventh grade students" questioning skill using "Question Student Have" method in SMP Negeri 1 Sinjai. The instrument for the research was observation which using checklist form about students' participation in questioning in Indonesian learning. In analyzing the data, the researcher used descriptive analysis and inferential analysis. The result showed that the "Question Student Have" method was effective to be implemented in Indonesian teaching and learning. This is proven by the result of data observation in which the students' (in experiment class) participation and enthusiastic in questioning is bigger than the students who were in control class. It is indicated by the average score of the students' in experiment class were higher than the students' average score in control class which the scores were 5,75 (experiment class) and 3, 38 (control class). Besides, the statistic showed that $t$ count $>t$ table $=4,90>2,00$ and the significance was 5\% which means the hypothesis was accepted.
\end{abstract}

Keywords: Questioning Skill, Question student have method

\begin{abstract}
Abstrak : Penelitian ini dimaksudkan untuk membuktikan keefektifan pembelajaran keterampilan bertanya dengan metode question student have siswa kelas VII SMP Negeri 1 Sinjai. Teknik pengumpulan data dalam penelitian ini adalah observasi dengan instrumen yang berupa daftar ceklis tentang keaktifan siswa bertanya dalam pembelajaran bahasa Indonesia. Data yang terhimpun dianalisis dengan menggunakan teknik analisis deskriptif dan inferensial. Hasil penelitian ini menunjukkan bahwa metode question student have efektif diterapkan dalam pembelajaran keterampilan bertanya. Hal ini dinyatakan karena keaktifan dan antusiasme siswa di kelas eksperimen lebih besar dibandingkan siswa pada kelas kontrol. Selain itu, nilai rata-rata siswa kelas eksperimen lebih tinggi dibandingkan nilai rata-rata kelas kontrol, yaitu 5,75 dan 3,38. Selain itu hasil statistik menunjukkan bahwa t hitung $>\mathrm{t}$ tabel $=4,90>2,00$ taraf signifikan $5 \%$ yang berarti hipotesis penelitian ini diterima.
\end{abstract}

Kata Kunci: Keterampilan Bertanya, Metode question student have

Manazhim : Jurnal Manajemen dan Ilmu Pendidikan

Volume 1, Nomor 2, Agustus 2019; 104-116

https://ejournal.stitpn.ac.id/index.php/manazhim 


\section{PENDAHULUAN}

Kurikulum Tingkat Satuan Pendidikan (KTSP) menuntut peserta didik mampu menguasai empat keterampilan berbahasa. Salah satu keterampilan berbahasa yang harus dikuasai peserta didik ialah keterampilan berbicara. Keterampilan berbicara merupakan satu rangkaian dari kreativitas bertanya. Setelah terampil bertanya, maka secara umum dapat dikatakan bahwa seseorang telah menguasai keterampilan berbicara. Berbicara adalah segala sesuatu yang berhubungan dengan tindakan menyatakan sesuatu kepada orang lain dalam bentuk bahasa lisan ${ }^{1}$ (Tarigan, 2008). Pengertian tersebut memberikan gambaran bahwa berbicara adalah aktivitas manusia dengan bahasanya yang terwujud dalam kegiatan berkomunikasi secara lisan.

Pada dasarnya, masih banyak siswa yang beranggapan bahwa kegiatan berkomunikasi yang erat kaitannya dengan kegiatan berbicara, khususnya berbicara di depan umum merupakan hal yang sangat menakutkan. Hal ini disebabkan oleh kurangnya pengalaman untuk berinteraksi dalam setiap kegiatan berbicara. Melalui pengalaman demi pengalaman, maka perasaan takut untuk berbicara di depan umum akan hilang dengan sendirinya. Oleh karena itu, seorang guru yang profesional harus mampu memiliki keterampilan dan memilih metode yang tepat untuk dapat meningkatkan prestasi belajar siswanya, khususnya dalam belajar bahasa dan sastra Indonesia dengan baik dan benar.

Hasil survei dan wawancara antara peneliti dengan guru dan siswa kelas VII SMP Negeri 1 Sinjai, diperoleh informasi bahwa kegiatan pembelajaran keterampilan bertanya siswa masih sangat kurang. Hal ini dikarenakan kurangnya variasi metode yang digunakan oleh guru dalam pembelajaran keterampilan bertanya maupun keterbatasan kemampuan bertanya siswa itu sendiri. Pada dasarnya, guru hanya menggunakan metode konvensional dalam proses pembelajaran.

Salah satu upaya untuk meningkatkan keterampilan bertanya siswa kelas VII SMP Negeri 1 Sinjai ialah menerapkan metode question student have. Penerapan metode tersebut akan menstimulus siswa untuk memberikan pertanyaan yang berhubungan dengan materi yang belum dipahaminya. Berdasarkan hal tersebut, peneliti berinisiatif melakukan penelitian dengan judul “ Keefektifan Pembelajaran Keterampilan

\footnotetext{
1 Tarigan, Berbicara Sebagai Suatu Keterampilan Berbahasa, (Bandung:Angkasa, 2008), Edisi revisi, hlm.16.
} 
Bertanya dengan Metode Question Student Have Siswa Kelas VII SMP Negeri 1 Sinjai”. Hal ini dimaksudkan untuk memberikan gambaran tentang keterampilan bertanya siswa dengan metode question student have.

\section{TINJAUAN PUSTAKA}

\section{Pengertian Berbicara}

Berbicara adalah segala sesuatu yang berhubungan dengan tindakan menyatakan sesuatu kepada seseorang dalam bentuk ujaran atau bahasa lisan (Tarigan, 2008:16). Lebih lanjut, Mulgrave (dalam Tarigan, 2008:16) mengemukakan bahwa berbicara adalah suatu alat untuk mengomunikasikan gagasan-gagasan yang disusun serta dikembangkan sesuai dengan kebutuhan-kebutuhan sang pendengar atau penyimak. Pengertian tersebut memberikan gambaran bahwa berbicara adalah aktivitas manusia dengan bahasanya terwujud dalam kegiatan berkomunikasi secara lisan. Atas dasar itu, berbicara dapat dipahami sebagai seni kemampuan menyatakan pendapat, mengemukakan gagasan, menyampaikan informasi kepada orang lain secara efektif dengan menggunakan bahasa lisan sebagai alatnya.

\section{Keterampilan Bertanya}

Keterampilan bertanya menurut Marno (2008:115) adalah suatu pengajaran itu sendiri, sebab pada umumnya guru dalam pengajarannya selalu melibatkan/menggunakan tanya jawab. Keterampilan bertanya merupakan keterampilan yang digunakan untuk mendapatkan jawaban/balikan dari orang lain. Keterampilan dasar mengajar bertanya dapat kita kelompokkan menjadi dua tingkatan, yaitu keterampilan dasar mengajar bertanya tingkat dasar dan keterampilan dasar mengajar tingkat lanjut. Keterampilan bertanya tingkat dasar mempunyai beberapa komponen dasar yang perlu diterapkan dalam mengajukan segala jenis pertanyaan. Sementara itu, keterampilan bertanya tingkat lanjut merupakan lanjutan dari keterampilan dasar mengajar bertanya tingkat dasar, dan berfungsi untuk mengembangkan kemampuan berpikir peserta didik. ${ }^{2}$

${ }^{2}$ Ibid.,hlm. 115. 


\section{Tujuan Bertanya}

Keterampilan bertanya perlu kita pelajari sebagai pendidik sebab ada banyak tujuan kita mempunyai jenis keterampilan ini yaitu:

1. Membangkitkan minat dan rasa ingin tahu peserta didik terhadap suatu masalah yang sedang dibicarakan;

2. Memusatkan perhatian siswa pada suatu masalah yang sedang dibahas;

3. Mendiagnosis kesulitan-kesulitan khusus yang menghambat peserta didik dalam belajar;

4. Mengembangkan cara belajar siswa aktif;

5. Memberikan kesempatan kepada siswa untuk mengasimilasikan informasi;

6. Mendorong siswa mengemukakan pendapat dalam diskusi;

7. Menguji dan mengukur hasil belajar.

\section{Prinsip Keterampilan Bertanya}

Kalau kita ingin mempunyai keterampilan bertanya yang baik, kita dapat mencermati prinsip-prinsip penggunaan keterampilan bertanya berikut ini:

1. Kehangatan dan antusias;

2. Kebiasaan yang perlu dihindari, yakni jangan mengulang-ulang pertanyaan apabila peserta didik tidak mampu menjawabnya. Hal ini dapat menyebabkan menurunnya perhatian dan partisipasi peserta didik;

3. Jangan menjawab sendiri pertanyaan yang diajukan sebelum peserta didik memperoleh kesempatan untuk menjawabnya;

4. Menentukan siswa yang harus menjawab sebelum mengajukan pertanyaan. Hasibu Abimanya, dalam Suwarna (2006:76). ${ }^{3}$

\section{Metode Question Student Have}

Metode Question Student Have dapat diartikan sebagai pertanyaan yang dimiliki siswa. Pertanyaan ini bisa dalam bentuk soal atau masalah lain yang berhubungan dengan materi yang belum dipahaminya. Menurut Silberman (2006:91) “ini merupakan cara yang tidak membuat siswa takut untuk mempelajari apa yang mereka

\footnotetext{
${ }^{3}$ Suwarna, "Prinsip Keterampilan Bertanya", https://afidburhanuddin.wordperss.com.hlm. 1.
} 
butuhkan dan harapkan. Cara ini memanfaatkan teknik yang mengundang partisipasi melalui penulisan". Metode ini bisa menyemarakkan lingkungan belajar aktif dengan memberi siswa kesempatan untuk bergerak secara fisik, berbagi pendapat untuk mencapai sesuatu yang mereka banggakan (Silberman, 2006:64). Dari kutipan ini, dapat diambil kesimpulan bahwa metode question student have dapat membuat siswa aktif dalam proses pembelajaran. Metode ini mewajibkan siswa menuliskan pertanyaan yang berupa soal atau masalah lain yang berhubungan dengan materi yang belum dipahaminya dalam secarik kertas. ${ }^{4}$

\section{Langkah-langkah Metode Question Student Have}

Hartono (2008), mengemukakan langkah-langkah dalam metode pembelajaran question student have sebagai berikut:

1. Bagikan kartu kosong kepada siswa;

2. Meminta kepada siswa menulis pertanyaan tentang mata pelajaran yang sedang dipelajari;

3. Putarlah kartu tersebut searah keliling jarum jam. Ketika setiap kartu diedarkan pada siswa berikutnya, peserta tersebut harus membacanya dan memberikan tanda cek jika pertanyaan ingin mereka ajukan;

4. Saat kartu kembali pada penulisnya, setiap siswa telah memeriksa semua pertanyaan yang diajukan oleh kelompok tersebut. Langkah ini akan mengidentifikasi pertanyaan mana yang banyak dipertanyakan. Jawab masingmasing pertanyaan tersebut dengan jawaban langsung atau memberikan jawaban kepada siswa yang berani menjawab pertanyaan. Menunda jawaban dari pertanyaan-pertanyaan tersebut sampai waktu yang tepat, meluruskan pertanyaan yang tidak menunjukkan suatu pertanyaan;

5. Panggil beberapa siswa berbagi pertanyaan secara sukarela, sekalipun pertanyaan mereka tidak memperoleh suara terbanyak;

6. Kumpulkan semua kartu. Kartu tersebut mungkin berisi pertanyaanpertanyaan yang mungkin dijawab pada pertemuan berikutnya.

\footnotetext{
${ }^{4}$ Agus Suprijono, Cooperative Learning, Teori \& Aplikasi PAIKEM (Yogyakarta:Pustaka Pelajar, 2009), Cet. 1 , hlm.108.
} 


\section{Kelebihan dan kelemahan Metode Question Student Have}

Menurut Hartono (2008), metode pembelajaran question student have memiliki kelebihan dan kelemahan sebagai berikut:

1. Kelebihan : Pelaksanaan proses pembelajaran ditekankan pada keaktifan belajar siswa dan keaktifan guru dalam menciptakan lingkungan belajar yang serasi dan menantang pola interaksi siswa;

2. Siswa termotivasi dalam belajar dan siswa akan mendapat kemudahan dalam menerima dan memahami materi yang diajarkan karena terjadi timbal balik antara guru dan siswa;

3. Mendapat partisipasi siswa melalui tulisan, sehingga sangat baik bagi siswa yang kurang berani mengungkapkan pertanyaan, keinginan, dan harapanharapan melalui percakapan;

4. Siswa tidak hanya mendengarkan tetapi perlu membaca, menulis, dan berdiskusi dan mendorong siswa untuk berpikir dalam memecahkan suatu soal dan menilai penguasaan siswa tentang bahan pelajaran, membangkitkan minat siswa sehingga akan menimbulkan keinginan untuk mempelajarinya juga menarik perhatian siswa dalam belajar;

5. Dapat menjaga perhatian siswa agar tetap tertuju pada proses pembelajaran, memperkuat dan memperlancar stimulus respon siswa, sehingga pembelajaran lebih menyenangkan dan mampu memberi kesan yang mendalam pada diri siswa;

6. Guru lebih mengetahui di mana letak ketidakpahaman siswa, karena semua siswa sudah mengajukan pertanyaan dan akan didiskusikan;

7. Kelemahan: memakan waktu yang banyak;

8. Tidak semua materi pelajaran bisa digunakan metode tersebut, misalnya pada materi pelajaran singkat karena tidak terlalu banyak pertanyaan yang akan diajukan siswa. ${ }^{5}$

\footnotetext{
${ }^{5}$ Hartono, "Kelebihan \& kelemahan metode question student have", fatkhan.web.id >questionsstudents-have
} 


\section{Pembelajaran Keterampilan Bertanya dengan Metode Question Student Have}

Agus (2009: 79-80), mengemukakan bahwa proses pembelajaran kontekstual beraksentuasi pada pemrosesan informasi, individualisasi, dan interaksi sosial. Guru sebagai individu memiliki andil yang cukup besar harus mengusahakan segala cara agar siswa bertanya baik secara lisan maupun tulisan, sebab hal ini akan berpengaruh besar terhadap proses pembelajaran. Adapun cara yang lebih mudah dalam mengajukan pertanyaan yaitu disampaikan secara lisan. Akan tetapi, mengingat banyaknya siswa yang kurang berani mengungkapkan pertanyaannya, maka perlu diupayakan suatu metode yang menuntut siswa untuk bertanya melalui tulisan sebagai langkah awal untuk memberi stimulus kepada siswa dengan harapan siswa pada akhirnya akan terbiasa, berani, dan mampu bertanya secara lisan. metode yang dimaksud ialah metode question student have. ${ }^{6}$

\section{METODE PENELITIAN}

Penelitian ini merupakan penelitian eksperimen. Desain penelitian yang digunakan dalam penelitian ini adalah eksperimen control group design (Arikunto, 2006) dengan melibatkan dua kelompok, yaitu kelompok/kelas eksperimen (menggunakan metode question student have dalam pembelajaran keterampilan bertanya), dan kelompok/kelas kontrol (tidak menggunakan metode question student have dalam pembelajaran keterampilan bertanya). Adapun populasi yaitu keseluruhan siswa kelas VII SMP Negeri 1 Sinjai dengan jumlah 320 siswa yang terbagi dalam sepuluh kelas. Penarikan sampel menggunakan teknik purposive sampling (sampel bertujuan). Artinya, penentuan sampel dengan menggunakan sampel penelitian sesuai dengan tujuan dan karakteristik dalam penelitian ini. Jadi, sampel dalam penelitian ini adalah kelas VII 1 sebagai kelas eksperimen dan kelas VII 2 sebagai kelas kontrol. Kelas tersebut dipilih berdasarkan informasi dari pihak sekolah yang menyatakan bahwa kemampuan siswa tersebut relatif sama atau homogen.

Teknik pengumpulan data dalam penelitian ini ialah observasi dengan instrumen yang berupa daftar ceklis tentang keaktifan siswa bertanya, wawancara dengan guru mata pelajaran bahasa Indonesia, dan tes yang diberikan kepada siswa

${ }^{6}$ Agus Suprijono, Cooperative Learning, Teori \& Aplikasi PAIKEM (Yogyakarta:Pustaka Pelajar, 2009), Cet. 1, hlm.79-80. 
kelas eksperimen dan kelas kontrol. Dalam penelitian ini, data yang telah terkumpul dianalisis dengan menggunakan teknik statistik deskriptif dan analisis statistik inferensial. Analisis statistik deskriptif dimaksudkan untuk menggambarkan karakteristik keterampilan bertanya siswa yang meliputi: nilai tertinggi, nilai terendah, nilai rata-rata, standar deviasi, dan tabel distribusi frekuensi. Kriteria tersebut digunakan untuk menentukan kategori keterampilan bertanya siswa kelas eksperimen dan kelas kontrol SMP Negeri 1 Sinjai. Sedangkan analisis statistik inferensial digunakan untuk menguji hipotesis penelitian dengan menggunakan uji-t.

\section{HASIL PENELITIAN DAN PEMBAHASAN}

\section{Penyajian Hasil Analisis Data}

\section{Analisis Deskriptif Data Kelas Kontrol}

Kelas VII 2 (kelas kontrol) terdapat 32 siswa. Berdasarkan hasil analisis data, dari 32 siswa, tidak ada yang memperoleh skor 9 sebagai skor maksimal. Skor tertinggi yang dicapai siswa ialah 7 yang diperoleh satu orang siswa dan skor terendah yang dicapai siswa adalah 0 yang diperoleh satu orang siswa. Perolehan skor siswa dari skor tertinggi sampai skor terendah secara berurutan dapat diuraikan sebagai berikut: skor tertinggi yang dicapai siswa yaitu 6-7 diperoleh empat orang siswa (12,50\%), siswa yang memperoleh skor 4-5 diperoleh sebelas orang siswa $(34,38 \%)$, siswa yang memperoleh skor 2-3 diperoleh empat belas orang siswa $(43,75 \%)$, sedangkan siswa yang memperoleh skor $0-1$ diperoleh tiga orang siswa $(9,38 \%)$.

Tabel Distribusi Frekuensi dan Persentase Skor Siswa Kelas Kontrol

\begin{tabular}{|c|c|c|c|}
\hline No & Interval & Frekuensi & Persentase (\%) \\
\hline 1 & $0-1$ & 3 & 9,38 \\
\hline 2 & $2-3$ & 14 & 43,75 \\
\hline 3 & $4-5$ & 11 & 34,38 \\
\hline 4 & $6-7$ & 4 & 12,50 \\
\hline 5 & $8-9$ & $\mathbf{0}$ & 0,00 \\
\hline \multicolumn{2}{|c|}{ Jumlah } & 32 & 100,00 \\
\hline
\end{tabular}


Berdasarkan hasil analisis deskriptif tersebut, diperoleh rangkuman tingkat keterampilan bertanya siswa pada berbagai karakteristik distribusi nilai. Untuk lebih jelasnya, rangkuman karakteristik distribusi nilai yang diperoleh siswa pada kelas kontrol ditunjukkan pada tabel di bawah ini.

Tabel Karakteristik Rangkuman Distribusi Nilai yang Menggambarkan Keterampilan Bertanya Siswa pada Kelas Kontrol

\begin{tabular}{|l|c|}
\hline \multicolumn{1}{|c|}{ Statistik } & Nilai Statistik \\
\hline Jumlah sampel/Subjek & 32 \\
\hline Skor Ideal & 9 \\
\hline Skor Tertinggi & 7 \\
\hline Skor Terendah & 0 \\
\hline Rentang Skor & 7 \\
\hline Rata-rata Skor & 3,38 \\
\hline Median & 3,29 \\
\hline Variansi & 2,694 \\
\hline Standar Deviasi & 1,641 \\
\hline
\end{tabular}

Berdasarkan tabel di atas, dapat diketahui bahwa di antara 32 siswa, nilai tertinggi yang diperoleh siswa adalah 7. Nilai terendah yang diperoleh siswa adalah 0; rentang skor 7; rata-rata skor 3,38; median 3,29; variansi 2,694; dan standar deviasi 1,641.

\section{Analisis Deskriptif Data Kelas Eksperimen}

Hasil analisis deskriptif data kelas VII 1 (kelas eksperimen) menggambarkan bahwa dari 32 siswa, ada siswa yang memperoleh skor 9 sebagai skor maksimal. Skor tertinggi yang dicapai oleh siswa ialah 9 yang diperoleh tiga orang siswa dan skor terendah yang dicapai siswa ialah 0 yang diperoleh satu orang siswa. Perolehan skor siswa dari skor tertinggi sampai skor terendah secara berurutan dapat diuraikan sebagai berikut: skor tertinggi yang dicapai siswa yaitu 8-9 diperoleh sembilan orang siswa $(28,13 \%)$, siswa yang memperoleh skor 6-7 diperoleh delapan orang siswa $(25,00 \%)$, siswa yang memperoleh skor 4-5 diperoleh sepuluh orang siswa $(31,25 \%)$, siswa yang memperoleh skor 2-3 diperoleh tiga orang siswa (9,38\%), sedangkan 
siswa yang memperoleh 0-1 diperoleh dua orang siswa ( 6,25\%). Gambaran lebih jelas dari skor terendah sampai dengan skor tertinggi yang diperoleh siswa beserta frekuensinya dapat dilihat pada tabel di bawah ini:

Tabel Distribusi Frekuensi dan Persentase Skor Siswa Kelas Eksperimen

\begin{tabular}{|l|c|c|c|}
\hline No & Interval & Frekuensi & Persentase (\%) \\
\hline 1 & $0-1$ & 2 & 6,25 \\
\hline 2 & $2-3$ & 3 & 9,38 \\
\hline 3 & $4-5$ & 10 & 31,25 \\
\hline 4 & $6-7$ & 8 & 25,00 \\
\hline 5 & $8-9$ & 9 & 28,13 \\
\hline \multicolumn{2}{|c|}{ Jumlah } & 32 & 100,00 \\
\hline
\end{tabular}

Berdasarkan hasil analisis deskriptif tersebut, diperoleh tingkat rangkuman keterampilan bertanya siswa pada berbagai karakteristik distribusi nilai. Untuk lebih jelasnya, rangkuman karakteristik distribusi nilai yang diperoleh siswa pada kelas eksperimen ditunjukkan pada tabel di bawah ini:

Tabel Karakteristik Rangkuman Distribusi Nilai yang Menggambarkan Keterampilan Bertanya Siswa pada Kelas Eksperimen

\begin{tabular}{|l|c|}
\hline \multicolumn{1}{|c|}{ Statistik } & Nilai Statistik \\
\hline Jumlah Sampel/Subjek & 32 \\
\hline Skor Ideal & 9 \\
\hline Skor Tertinggi & 9 \\
\hline Skor Terendah & 0 \\
\hline Rentang Skor & 9 \\
\hline Rerata Skor & 5,75 \\
\hline Median & 5,77 \\
\hline Variansi & 5,032 \\
\hline Standar Deviasi & 2,243 \\
\hline
\end{tabular}

Berdasarkan tabel di atas, dapat diketahui bahwa di antara 32 orang siswa, nilai tertinggi yang diperoleh siswa adalah 9. Selanjutnya, nilai terendah yang diperoleh siswa adalah 0 ; rentang skor 9; rerata skor 5,75; median 5,77; variansi 5,032; dan standar deviasi 2,243. 


\section{Analisis Keefektifan Pembelajaran Keterampilan Bertanya dengan} Metode Question Student Have Siswa Kelas VII SMP Negeri 1 Sinjai

Setelah diadakan perhitungan berdasarkan hasil statistik inferensial (eksperimen) jenis uji t, diperoleh nilai t hitung : 4,90 pada taraf signifikan 5\% diperoleh t.s $0,05=2,00$. Kriteria pengujiannya adalah hipotesis alternatif (HI) diterima apabila t hitung lebih besar dari $t$ tabel ( $\mathrm{t}$ hitung $>\mathrm{t}$ tabel) dan hipotesis alternatif (HI) ditolak apabila t hitung lebih kecil atau sama dengan $\mathrm{t}$ tabel ( $\mathrm{t}$ hitung $<\mathrm{t}$ tabel). Jadi, t hitung $(4,90)>\mathrm{t}$ tabel $(2,00)$. Berdasarkan perhitungan tersebut, maka HI diterima dan Ho ditolak. Dengan demikian ada perbedaan secara signifikan antara pembelajaran keterampilan bertanya dengan menggunakan metode question student have dengan pembelajaran keterampilan bertanya tanpa menggunakan metode question student have pada siswa kelas VII SMP Negeri 1 Sinjai.

\section{PEMBAHASAN}

Berdasarkan hasil analisis data perbandingan skor rerata hasil tes siswa antara kelas eksperimen dan kelas kontrol dengan menggunakan rumus uji $t$, dapat diketahui nilai t hitung diperoleh sebesar 4,90 pada taraf signifikan 5\% diperoleh t.s $0,05=$ 2,00. jadi, t hitung $>\mathrm{t}$ tabel. Karena $\mathrm{t}$ hitung $>\mathrm{t}$ tabel pada taraf signifikan 5\%, maka hipotesis nol (Ho) ditolak dan hipotesis alternatif (HI) diterima. Hal ini berarti bahwa ada perbedaan secara signifikan antara pembelajaran keterampilan bertanya dengan menggunakan metode question student have dengan pembelajaran keterampilan bertanya tanpa menggunakan metode question student have pada siswa kelas VII SMP Negeri 1 Sinjai.

Penggunaan metode question student have dianggap efektif untuk diterapkan karena siswa dapat termotivasi dalam belajar dan siswa mendapatkan kemudahan dalam menerima dan memahami materi yang diajarkan karena terjadi interaksi yang baik antara guru dan siswa. Sedangkan pada kelas kontrol, siswa hanya diberikan materi oleh guru dengan menggunakan metode konvensional (ceramah dan tanya jawab). 


\section{KESIMPULAN}

Berdasarkan hasil penelitian tersebut, maka peneliti menyimpulkan:

1. Berdasarkan hasil analisis deskriptif data kelas kontrol, yaitu kelas VII.2 yang terdapat 32 siswa, dari 32 orang siswa tidak ada yang memperoleh skor 9 sebagai skor maksimal. Skor tertinggi yang dicapai oleh siswa, yaitu 7 yang diperoleh satu orang siswa, dan skor terendah yang dicapai siswa ialah 0 yang diperoleh satu orang siswa. Dengan demikian, nilai rerata kompetensi bertanya tanpa menggunakan metode question student have siswa kelas kontrol yaitu 3,38;

2. Hasil analisis deskriptif data kelas eksperimen, yaitu kelas VII.1 yang terdapat 32 siswa, dari 32 siswa ada yang memperoleh skor 9 sebagai skor maksimal. Skor tertinggi yang dicapai oleh siswa yaitu 9 yang diperoleh tiga orang siswa dan skor terendah yang dicapai siswa ialah 0 yang diperoleh satu orang siswa. Dengan demikian, nilai rerata kompetensi bertanya dengan menggunakan question student have siswa kelas eksperimen yaitu 5,75;

3. Hasil analisis statistik inferensial, diperoleh hasil nilai t hitung sebesar 4,90 pada taraf signifikan 5\% diperoleh t.s $0,05=2,00$ dan dapat dikatakan bahwa t hitung lebih besar dari t tabel $(4,90>2,00)$. Jadi dapat disimpulkan bahwa ada perbedaan secara signifikan antara pembelajaran keterampilan bertanya dengan menggunakan metode question student have dengan pembelajaran keterampilan bertanya tanpa menggunakan metode question student have pada siswa kelas VII SMP Negeri 1 Sinjai;

4. Berdasarkan hasil analisis deskriptif dan analisis inferensial, dapat disimpulkan bahwa metode question student have efektif diterapkan dalam pembelajaran keterampilan bertanya siswa kelas VII SMP Negeri 1 Sinjai.

\section{SARAN}

1. Siswa diharapkan dapat bersungguh-sungguh dalam bertanya karena sangat penting untuk mengembangkan daya pikir dalam berkomunikasi;

2. Guru bahasa Indonesia, kiranya selalu memberikan pelatihan dan tugas berbicara khususnya bertanya, kemudian memberikan penilaian dan memberitahukan letak kesalahan terhadap performance atau penampilannya, 
serta mencoba untuk menggunakan metode question student have dalam pembelajaran keterampilan bertanya;

3. Kepada pihak yang berwenang dalam bidang pendidikan, kiranya dapat mengupayakan kelengkapan sarana mengajar pada umumnya dan materi bahasa Indonesia pada khususnya;

4. Bagi peneliti selanjutnya, diharapkan dapat melakukan penelitian tindakan kelas (PTK) dengan menggunakan metode question student have sebagai lanjutan dari penelitian ini.

\section{DAFTAR PUSTAKA}

Arikunto, Suharsimi. 2006. Prosedur Penelitian Suatu Pendekatan Praktik. Jakarta: Rineka Cipta.

Arsjad, Maidar G. 1988. Pembinaan Kemampuan Berbicara Bahasa Indonesia. Jakarta: Erlangga.

Djumingin, Sulastriningsih. 2007. Strategi Belajar-Mengajar Babasa dan Sastra Indonesia Serta Penerapannya. Makassar: Badan Penerbit UNM.

Mudini dan Salamat Purba. 2009. Pembelajaran Berbicara. Jakarta: Depdiknas.

Muslich, Masnur. 2007. KTSP Dasar Pemahaman dan Pengembangan. Jakarta: Bumi Aksara

Nurgiyantoro, Burhan. 2009. Penilaian dalam Pengajaran Bahasa dan Sastra. Yogyakarta: BPFE-Yogyakarta.

Patombongi, A. Wardihan dkk. 2008. Telaah Kurikulum Bahasa Indonesia. Makassar: Badan Penerbit UNM.

Sugiyono. 2013. Metode Penelitian Pendidikan: Pendekatan Kuantitatif, Kualitatif dan R\&D. Cetakan ke-18 Bandung: Alfabeta.

Suprijono, Agus. 2010. Cooperative Learning Teori dan Aplikasi PAIKEM. Yogyakarta: Pustaka Pelajar.

Syafi'i, Imam. 1988. Retorika dalam Menulis. Jakarta: Depdikbud.

Tarigan, H.G. 2008. Berbicara Sebagai Suatu Keterampilan Berbahasa. Bandung: Angkasa.

Tiro, M. Arif. 2007. Statistika Terapan. Makassar: Andira Publisher. 